\title{
6 Discourse, Power, Ideology: Humanism and Postmodernism
}

\section{Linda Hutcheon}

1

Figurations, usually of an ideological origin whether acknowledged or no, will be found in history as well as in the history-like. (Frank Kermode)

In the postmodern 'history-like' - be it in architecture, the visual arts, or literature - the ideological and the aesthetic are turning out to be inseparable. The overt and self-implicating paradox of self-reflexivity meeting historical grounding in the postmodern fiction of, for example, Rushdie, Fowles, Eco or Doctorow resists any temptation to see ideology as that which only others fall prey to. What postmodern theory and practice have taught is less that 'truth' is illusory than that it is institutional, for we always act and use language in the context of politico-discursive conditions (Eagleton 1986: 168). Ideology both constructs and is constructed by the way in which we live our role in the social totality (Coward and Ellis 1977: 67), and by the way we represent that process in art. Its fate, however, is to appear as natural, ordinary, commonsensical. Our consciousness of ourselves is usually, therefore, uncriticized because it is familiar, obvious, transparent (Althusser 1969: 144).

When these practical norms move from asserting how things are to claiming how they ought to be, we can begin to see the connections between ideology and existing relations of power. From the earlier Marxist notion of ideology as false consciousness or an illusory belief system, we have moved, in current critical discourse, to a different notion of ideology as a general process of production of meaning (Williams 1977: 55). In other words, all social practice (including art) exists by and in ideology (Coward and Ellis 1977: 72), and as such, ideology comes to mean 'the ways in which what we say and believe connects with the power-structure and power-relations of the society we live in' (Eagleton 1983: 14). Much of the impetus to this redefining of ideology and to its newly important position in recent discussions of art has come from a reaction against the liberal humanist suppression of the historical, political, material and social in the definition of art as eternal and universal. Postmodern theory and practice have worked to contest this suppression, but in such a way that their implication in the underlying humanist value system cannot be ignored. 
Postmodern fiction - that is, what I would like to call 'historiographic metafiction' - foregrounds the problematic and complex relationship that has always existed between the formal concept of the text and the socio-political one of ideology. It also demands a concept of ideology that is concerned equally with dominant and with oppositional strategies (Kress 1985: 29), for it incarnates the contradictions of their interaction. The romantic and modernist heritage of non-engagement insists that art is art and that ideological discourse has no place in the literary (see Graff 1983). Added to this historical separation is a suspicion of the artistic that is general in much of the Anglo-American world, a view that sees art as trivial, insignificant, imaginative and therefore cut off from the social and historical realities of life. This is a view implicitly shared by commentators from both ends of the political spectrum, from the neoconservative to the Marxist.

Nevertheless, postmodernist art and theory have self-consciously acknowledged their ideological positioning in the world, and they have been caused to do so not only in reaction to that provocative assertion of triviality, but also by those previously silenced 'ex-centrics', both outside and inside the supposedly monolithic culture of the West These are the 'different', those whose marginalization has taught them that artists should indeed have "inherent political status because they are perceived as dealing with belief' (Sukenick 1985: 82). I am reminded of that scene in Salman Rushdie's Shame in which the narrator attends a production of Georg Büchner's play, Danton's Death, in a largely empty theatre: 'Politics empties theatres in Old London town' (Rushdie 1983: 240). However, his three guests, visitors from Pakistan, love just being in a country where such plays can even be performed. They tell the story of the military censors at home, preventing a production of Julius Caesar because it depicted the assassination of a head of state - until a British diplomat was persuaded to play Caesar, and Shakespeare's play could become a patriotic call for the overthrowing of imperialism. The narrator adds, forestalling our response, 'I insist: I have not made this up'.

What is at stake in this debate about the relation of the ideological to the aesthetic is the status and definition of art as an institution. With postmodern examples like Rushdie's it is hard to avoid seeing literature as part of 'the apparatus of officialdom that maintains the social and cultural status quo' (Sosnoski 1985: 93). The dominant liberal humanist tradition, in which many of us were trained and in which we still, largely, teach and write, has usually insisted on art's apolitical uncontamination by such overtly ideological agencies. But, as many an oppositional critic has insisted lately, what our official literature curricula are intended to teach (the 'great tradition') is not all they impart. Teaching and writing are forms of institutional politics (see Widdowson 1982). As a category, Tony Bennett has argued, literature 'refers not to the concept of a privileged set of texts which exemplify a universal and eternal aesthetic form of cognition but to a specific practice of writing, bound, circumscribed and conditioned by the historical, material and ideological conditions of its production' (Bennett 1979: 15). Postmodernist thought would add, "and of its reception too'. Such a view recognizes the literary, not as separate (and therefore either privileged or trivialized), but rather as one practice of writing among others, all equally institutionalized: history; biography; philosophy; criticism; theory. This too is the overt lesson of postmodernism's rethinking of the boundaries of these same discourses.

It is the novel genre in particular that has become the battleground for much of this asserting - and contesting - of liberal humanist beliefs about the status and identity of art. Ian Watt's (already ideological) analysis of the rise of the English novel, for instance, has been further politicized lately by those readings of the genre in the light of class and, of course, gender. Lennard Davis has shown that the prevailing theory of the novel at its beginnings (as moral, conservative) must be contrasted with the reality of the form itself (as morally ambiguous and ambivalently both radical and conservative) (Davis 1980: 113). This would suggest that those postmodern paradoxes of historiographic metafiction are perhaps inherent in the novel as a genre - as defined by Davis as a doubled discourse which ambiguously embodies opposing political and moral functions. That is to say, the novel is potentially dangerous not just because it is a reaction against social repression, but because it also works to authorize that very power of repression at the same time (117). What postmodern fiction does, however, is to reverse that doubled process: it installs the power, but also contests it. Nevertheless, the contradictory doubleness remains.

The literary history of the novel has been inseparable from that of realism. Today, many want to claim that realism has failed as a method of novelistic representation because life now is just too horrific or too absurd. But, surely, Dickens saw nineteenth-century London as both horrific and absurd, yet he used realism as his mode of ordering and understanding what he saw, and thus of creating what we read. It is perhaps this function of realism that we have come to question today, in our self-consciousness about (and awareness of the limits of) our structuring impulses and their relation to the social order. Gerald Graff once tied Eliot's declaration of the obsolescence of fictional realism (in a review of Joyce's Ulysses) to the end of the 'world-view of liberal bourgeois individualism, with its optimistic belief in progress and the rational intelligibility of experience' (Graff 1975: 306). Life has not changed, then; but our faith in our ability to make sense of it might have. So too might our belief that any sense we might make could confidently lay claim to universality or 'truth'. Postmodernism suggests that the language in which realism - or any other mode of representation - operates cannot escape ideological 'contamination'. However, it also reminds us, by its very paradoxes, that awareness of ideology is as much an ideological stand as commonsensical unawareness of it. The link between realism and liberal humanism is a historically verifiable 
one (see Belsey 1980; Waugh 1984), but the postmodern contesting of both is just as ideologically inspired, and considerably more ambivalent.

The postmodern novel, in other words, does not (as Bakhtin claimed of the genre as a whole) begin 'by presuming a verbal and semantic decentring of the ideological world' (Bakhtin 1981: 367). It begins by creating and centring a world - Saleem Sinai's India (Midnight's Children) or Tom Crick's fen country (Waterland) - and then contesting it. Historiographic metafictions are not 'ideological novels' in Susan Suleiman's sense of the word: they do not 'seek, through the vehicle of fiction, to persuade their readers to the "correctness" of a particular way of interpreting the world' (Suleiman 1983: 1). Instead, they make their readers question their own (and by implication, others') interpretations. They are more 'romans à hypothèse' than 'romans à thèse'.

Art and ideology have a long history of mutual interaction - and recuperation - that undercuts the humanist and the more recent formalist separation of the two. Verdi's Israelite chorus, singing of its desire for a homeland (in Nabucco), was greeted by its first northern Italian audiences as singing their song, in an allegory of their desire to free themselves from Austro-Hungarian rule; it remains the unofficial national anthem of Italy today. In John Berger's postmodern novel, $G$., the revolutionary crowds gather in northern Italian cities around statues of Verdi, whose very name has come to stand for freedom (but only for some - it means oppression for others): V(ictor) E(mmanuele) R(e) D' I(talia). Berger's text has its own overtly ideological focus which calls our attention to this changing, but real, history of art's implication in the political.

In this novel, there is also a Livornese statue which plays an important allegorical role in the conjoining of the political and the aesthetic. It is a seventeenth-century representation of Ferdinand I, complete with naked and chained slaves adorning each of the four corners. These slaves, we are told, were modelled after local prisoners. This statue comes to be connected to the Risorgimento and then to the revolt of the new slaves - the workers - who have cast off their chains and come to life, in an ironic echoing (ironic because of the class inversion) of the Commendatore's statue in Mozart's Don Giovanni. But there are several levels of irony here. First of all, the 'slaves' who come to life are not just workers. Berger makes the connection between the ethnically oppressed of northern Italy - the Slavs (or sc'iavi) - and these slaves (or schiavi). The hero (known only by the initial G.), though he may die for his political activities, is no resurrected Garibaldi, despite his nickname and his partly Italian blood. He is, if anything, a Don Giovanni, so his death makes intertextual, if ironic, sense. Yet the historical Garibaldi's absent presence haunts the novel, from its early claim that its "principal protagonist was conceived four years after Garibaldi's death' (Berger 1972: 20). This statement is followed by a long section on the importance of Garibaldi's particular blend of innocence and patriotism to Italian identity and politics. The novel's $G$. is neither innocent nor patriotic, however, so the link is again a deliberately ironic one.

Postmodern fiction - like Brecht's drama - often tends to use its political commitment in conjunction with distancing irony like this and technical innovation, in order to both illustrate and incarnate its teachings. Cortázar's A Manual for Manuel becomes a didactic manual for the revolutionaries' son, Manuel, and the reader, both of whom 'come of age' in the reading of this text. The 'aura' of the original, genuine, single work of genius is replaced, as Benjamin foresaw, by the mechanical reproduction of fragments of history - here, of newspaper clippings embedded in the text we read. But what is gained is an ideological awareness both of the political, social, and linguistic repression in Latin America and also of the modes of possible resistance (see D'Haen 1983: 70-1). The social and historical contexts are made part of the physical text we read, thereby shifting, in Charles Russell's terms (about the work of those other postmodern writers, Robert Coover and Thomas Pynchon), 'the previous social context of rebellion to the social text of ideology' (Russell 1985: 253).

2

Criticism and interpretation, the arts of explanation and understanding, have a deep and complex relation with politics, the structures of power and social value that organize human life. (W. J. T. Mitchell)

Just as metafictional self-consciousness is nothing new (think of Tristram Shandy, not to mention Don Quixote), so this merging of the ideological and the self-reflexively literary in a historical context is not radically innovative in itself: witness Shakespeare's history plays' selfconsciously critical involvement of their audience in the questioning of social action and authority, past and present (Belsey 1980: 95-102). But the particular concentration of these concerns in the theory and practice of today suggests that, here, there may be something we could call part of a poetics of postmodernism. Of all current forms, it is postmodern fiction that, for me, best illustrates the paradoxes of this cultural enterprise. Its self-consciousness about its form prevents any occultation of the literary and linguistic, but its problematizing of historical knowledge and ideology works to foreground the implication of the narrative and the representational in our strategies of making meaning in our culture.

One caution is in order, however. I am not saying that selfconsciousness is, by definition, revolutionary or even progressive. Metafiction does not necessarily lead to cultural relevance (cf. Waugh 1984: 18) any more than self-demystifying theory is inherently radical (witness Newman 1985). It is perhaps liberal to believe that any subversion or undermining of a system of thought is healthy and good, 
but it would also be naive to ignore that art can just as easily confirm as trouble received codes, no matter how radical its surface transgressions. Texts could, conceivably, work to dismantle meaning and the unified humanist subject in the name of right-wing irrationalism, as easily as left-wing defamiliarizing critique: think of the works of Céline, Pound, and others. Nevertheless, it has become almost a truism of postmodern criticism today that the deconstruction effected by metafictional self-consciousness is indeed revolutionary 'in the deepest sense' (Scholes 1980: 212). But the art of postmodernism itself suggests a somewhat less sure sense of the inherently revolutionary value of selfreflexivity. The humanist faith in the power of language can be turned in on itself, for historiographic metafiction often teaches that language can have many uses - and abuses. $\lambda$

Language can also be presented as limited in its powers of representation and expression. The self-conscious narrator of Berger's $G$. offers a verbal description of an event and then tells us: 'The description so far as it goes is accurate. But my power to select (both the facts and the words describing them) impregnates the text with a notion of choice which encourages the reader to infer a false range and type of choice ... Descriptions distort' (Berger 1972: 80). The important things, we learn, are beyond words, 'like an undescribed natural event'. These things are intensely real, however; indeed, more real because they are not articulated or named (159). Yet, paradoxically, the narrating writer has only language to work with and knows he is unavoidably 'a prisoner of the nominal, believing that things are what I name them' (137). Other historiographic metafictions - by writers as diverse as John Banville and Graham Swift - also frequently foreground the practical and theoretical consequences of that humanist faith in language, through their thematization and formal working-out of the ideological issues implicit in the novel genre"s representational and narrative identity.

One of the most extreme examples of metafictional self-theorizing about this and other humanist certainties is to be found in lan Watson's novel, The Embedding, in which the linguistic theories of Chomsky, the anthropological structuralism of Lévi-Strauss, and the political perspective of Marx meet to explicate and theorize the narrative's enactment of their implications regarding human mental processes, cultural action, and social organization. All of these theories are shown to be human constructs which can be made to operate in the interests of political power, as well as disinterested knowledge (though the two are inseparable here): they are all - potentially - discourses of manipulation. The constant intertextual presence of the intensely self-reflexive work of Raymond Roussel suggests the further contamination of both ideology with art and art with scientific knowledge, past and future. The real power of both self-referring language and knowledge turns out to be their shared ability to distance us from that brute reality with which no one in the novel seems able to cope. For one of the characters, the moment of panic is this one: 'The world was about to be embedded in his mind in its totality as direct sensory apprehension, and not as something safely symbolized and distanced by words and abstract thought' (Watson 1973: 251). The subjective and the cosmic, the personal and the public cannot be separated in this novel; nor can the aesthetic and the political.

Fiction like this is postmodern because in it language is inextricably bound to the social and the ideological (Kress and Hodge 1979: 15). Some kinds of contemporary criticism have been arguing on a theoretical level what postmodern fiction has meanwhile been busy illustrating as practice: that we need to examine critically the social and ideological implications operative in the institutions of our disciplines - historical, literary, philosophical, linguistic, and so on. The implication is that all theory is political theory, whether it is aware of it or not. In Terry Eagleton's terms:

Discourses, sign-systems and signifying practices of all kinds, from film and television to fiction and the languages of natural science, produce effects, shape forms of consciousness and unconsciousness, which are closely related to the maintenance or transformation of our existing systems of power. (Eagleton 1983: 210)

For example, current literary theories, especially deconstruction, have been linked to both authoritarian politics (Graff 1979) and revolutionary pedagogy (Ulmer 1985). They have been blamed for the decline of the humanities and exalted as the salvation of the intellectual credibility of the academy. As many have pointed out, deconstruction is certainly compatible with conservative politics (Ruegg 1979) and with a liberal humanist preservation of the canon (Leitch 1980), but there has also been a move to make it into the companion or completion of the Marxist project (Ryan 1982; Spivak 1980). While its oppositional image has made it attractive to leftists, deconstruction (as it is practised in North America) has tended to be apolitical in its exclusive focus on textuality (see Holub 1984: 86-7). We would be wise to heed Edward Said's warning about equating the radical and oppositional in a literary context with the same in a political one (Said 1983: 158-77). It is perhaps telling, too, that deconstructive critics have, by and large, concentrated on canonical texts and avoided postmodern ones which contest, within their own very form, the same notions of unity, originality, coherence, subjectivity, and rationality as does the criticism. The self-consciously theoretical nature of historiographic metafictions like The Name of the Rose, The Book of Daniel, or Midnight's Children might to some extent pre-empt the deconstructive critic's demystifying: their contradictions, or aporias, are overt - and functional. 
3

Fabrication is surrounded by and in constant contact with the world: action and speech are surrounded by and in constant contact with the web of the acts and words of other men. (Hannah Arendt)

What postmodernism's focus on its own context of enunciation has done is to foreground the way we talk and write within certain social, historical, and institutional (and thus, political and economic) frameworks. In other words, it has made us aware of 'discourse'. As Colin MacCabe has pointed out, the use of that word has become a kind of ideological flag in film (and other) criticism, signifying that the critic does not accept to analyse the formal articulation of a genre independently of its political and ideological address (MacCabe 1978-79: 41). As such, then, 'discourse' becomes an important and unavoidable term in discussions of postmodernism, of the art and theory that will not let us ignore social practices, the historical conditions of meaning, and the positions from which texts are both produced and received (see MacDonell 1986: 12). The diverse theoretical perspectives usually grouped together under the label of 'discourse analysis' share a mode of study which looks at authority and knowledge in their relation to power, and also at the consequences of the moment in history when "truth moved over from the ritualized act . . . of enunciation to settle on what was enunciated itself: its meaning, its form, its object and its relation to what it referred to' (Foucault 1972: 218).

This suppression of the enunciative act (and its responsibility) has led to the humanist separation of discourse from the exercise of power. Both postmodern art and theory work to reveal the complicity of discourse and power by re-emphasizing the enunciation: the act of saying is an inherently political act, at least when it is not seen only as a formal entity or in terms of what was said. In Foucault's words, this is a move to 'restore to discourse its character as an event' (Foucault 1972: 229), and thus to enable analysis of the controls and procedures by which discourse operates (216), both interpersonally and institutionally (Fowler 1981: 7). Art, theory, criticism are not really separable from the institutions (publishing houses, galleries, libraries, universities, etc.) which disseminate them and which make possible the very existence of a field of discourse and its specific discursive formations (the system of norms or rules that govern a certain way of thinking and writing at a certain time and place). So, when we speak of discourse, there is a concrete, material context involved.

Discourse, then, is both an instrument and an effect of power. This paradox is why it is so important to postmodernism. What Doctorow's Daniel learns by writing The Book of Daniel is that discourse is, in Foucault's terms, 'a hindrance, a stumbling-block, a point of resistance and a starting point for an opposing strategy' (Foucault 1980: 101). Discourse is not a stable, continuous entity that can be discussed like a fixed formal text; because it is the site of conjunction of power and
Discourse, Power, Ideology: Humanism and Postmodernism 113

knowledge, it will alter its form and significance depending on who is speaking, his/her position of power, and the institutional context in which the speaker happens to be situated (Foucault 1980; 100). Historiographic metafiction is always careful to 'situate' itself in its discursive context, and then uses that situating to problematize the very notion of knowledge - historical, social, ideological. Its use of history is not a modernist look to the 'authorizing past' (Conroy 1985) for legitimation; it is a questioning of any such authority as the basis of knowledge - and power. The narrator of $G$. is not content to explain the fact that G.'s mother wanted to be with her child all the time, in terms of general (or 'universal') categories, such as motherly love. He contextualizes it in its time and place and class, telling us that, in upper and middle-class Europe her desire 'would have been treated as hysterical. An infant, like everything else in the nineteenth century, had its own place - which was unshareable' (Berger 1972: 27).

It was Michel Foucault who was most responsible for problematizing the relation of discourse to power. Power, he argued, is omnipresent, not because it embraces all human action, but because it is constantly being produced: 'it is the moving substrate of force relations which, by virtue of their inequality, constantly engender states of power' (Foucault 1980: 93). Power is not a structure or an institution. It is a process, not a product. But postmodern thought inverts the power arrangements described by Foucault. He claims there is a doubled discourse: a disavowal and then reinscription of control or power. In postmodern art, there is, instead, an initial avowal or inscription, followed by a challenge to that. It too is doubled discourse but the terms differ, perhaps because it never sees itself as outside power relations the necessary position from which to be able to disavow. We can speak of power in art but also of the power of art (Selzer 1984: 87).

Power is also, of course, a dominant theme in historiographic metafiction's investigations of the relation of art to ideology. In William Kennedy's Legs, Jack Diamond's desire for money and power over people is matched by Kiki's sexual power and is shared by those in his employ: 'Wasn't it funny how fast Fogarty [Jack's man] could turn somebody's head around? Power in the word. In any word from Fogarty' (Kennedy 1975: 224). The power in the word (or the law) will not save Diamond, however, from the power of politics. Similarly, in $G$., the passivity of G.'s Uncle Jocelyn is explained in terms of the power of his economic class (the upper class) in Britain at the end of the last century: 'Their power was in no way threatened, but their own chosen image of themselves was threatened (Berger 1972: 31).

So power is not just a general novelistic theme in this kind of postmodern fiction. It also takes on powerful critical force in the incorporated and overt discourse of protest, especially that of class, gender and racial protest. Toni Morrison's Tar Baby, in fact, studies all three - class, racial, sexual power - in their wide range of manifestations and consequences, both present and historical. Language is once 
again shown to be a social practice, an instrument as much for manipulation and control as for humanist self-expression (see Fowler 1985: 61). There is no way that power here can be abstracted from material circumstances (cf. Kroker and Cook 1986: 73-113), for it is incarnate in the very bodies of the protagonists.

Postmodernism aims to interrogate and demystify totalizing systems that unify with an eye to power. Historiographic metafictions like Banville's Doctor Copernicus or Kepler challenge science, in particular, as a dominant, totalizing system, as the positivist adjunct to humanism, and they do so through an investigation of the role language plays in both knowledge and power. Of course, theory - from Vattimo's 'pensiero debole' to the neo-Neitzscheans' apocalyptic lamentations - has been doing the same thing. While the visual arts, music, dance and architecture contest received ideological notions as well, metafiction and what we might call metatheory do it specifically in terms of language, and in such a way as to link language to politics in a manner which humanistic and positivistic thought have both resisted. In Salman Rushdie's Shame, that link is established in these terms:

Islam might well have proved an effective unifying force in post-Bangladesh Pakistan, if people hadn't tried to make it into such an almighty big deal .. . Few mythologies survive close examination, however . . . So-called Islamic 'fundamentalism' does not spring, in Pakistan, from the people. It is imposed on them from above. Autocratic regimes find it useful to espouse the rhetoric of faith, because people respect that language, are reluctant to oppose it. This is how religions shore up dictators; by encircling them with words of power, words which the people are reluctant to see discredited, disenfranchised, mocked. (Rushdie 1983: 251)

The linguistic and the political, the rhetorical and the repressive - these are the connections postmodernism places in confrontation with that humanist faith in language and its ability to represent 'truth', past or present, historical or fictional. For instance, in Coover's The Public Burning, the novel's 'Richard Nixon' is neither excused nor derided. Instead, the novel focuses on the ideology that formed 'Nixon' (and Nixon) and does so 'in a context which foregrounds the problematic (and rhetorical) nature of historical interpretation' (Mazurek 1982: 33). The relations between language and fiction, language and history, language and criticism were once accepted as relatively unproblematic ones. Postmodernism attempts to change that.

Each class which puts itself in the place of the one ruling before it, is compelled, merely in order to carry through its aim, to represent its interests as the common interests of all members of society, that is, expressed in an ideal form: it has to give its ideas the form of universality and represent them as the only rational, universally valid ones. (Marx and Engels)

For many today, it is the 'rational, universally valid' ideas of our liberal humanist tradition that are being called into question. And postmodern art and theory are both playing a role in that questioning, while still acknowledging that they are inevitably, if unwillingly, part of that tradition. In other words, they have not yet seen themselves as being in the 'position of the one ruling before' them, and so have no needed to 'idealize' their position, but rather have contented themselves with a challenge from within, though from the margins. And they have contested these humanist values in full knowledge that they have also been under attack from many other directions. As postmodern novels like Star Turn and Gravity's Rainbow show, there is considerable anti-humanism to be found in mechanized, technocratic bureaucracies and in most regimes of power, be they capitalist, totalitarian, or socialist.

In that much-quoted essay, 'Marxism and Humanism', Althusser outlines how Marx, in 1845, broke with his earlier theories that based history and politics on an essence of 'Man', in order to argue that this bourgeois humanism - the view that each individual carries the whole of a timeless human essence within him/herself - was an ideology; that what had seemed transparent and unquestionable was neither. But what is of particular interest, from a postmodern perspective, is that, while Marx rejected the humanist pretensions to both (individual) empirical subjectivity and (universal) idealist essence, he also understood the practical function of both as ideology (Althusser 1969: 229). What historiographic metafiction also often does, is to show how these humanist notions are unavoidably connected to direct political and aesthetic issues as well.

The narrator of Shame considers trying the liberal humanist line that art is universal and timeless, in his defence of the book he could have written, one that would have included more 'real-life material' (Rushdie 1983: 69). However, he realizes the secret incompatibility of humanism and realism at a political level: 'By now', if I had written a book of this nature, it would have done me no good to protest that I was writing universally, not only about Pakistan. The book would have been banned' $(70)$. He ironically tells the reading authorities (including us) that what he has written is only fiction, 'a sort of modern fairy-tale and so '[n]o drastic action need be taken' (70). At the end, he returns to this ironic and protective frame and makes clear the political grounds upon which humanist assumptions are being contested: 'Well, well, mustn't forget I'm only telling a fairy-story. My dictator will be toppléd by goblinish, faery means. "Makes it pretty easy for you," is the obvious criticism; and I agree, I agree. But add, even if it does sound a little peevish: "You try and get rid of a dictator some time" (257). On one level, this is clearly not what Mas'ud Zavarzadeh calls a 'liberal- 
humanist novel' that claims to totalize, to offer an integrated view of existing realities (Zavarzadeh 1976: 4). Yet, on another level it is. It does offer $a$ view of existing realities, though it is one that is revealed to be deliberately contingent. It does order the chaos of experience, though it also then challenges that shaping process and the product of it, in very self-conscious ways.

Postmodern theory today has also challenged humanism's assumptions, and by 'postmodern theory' here I do not mean just the obvious: deconstruction, feminism, Marxism, and post-structuralism. The metatheoretical contesting of the assumption of timeless universality behind both art and much writing about art has also become frequent in semiotics, in art history, in psychoanalytic, sociological, and other fields, often organized around the concept of representation and its relation to subjectivity. How does culture represent the subject? How does it form part of the social processes of 'differentiation, exclusion, incorporation and rule' (Owens 1982: 10) that make representation the 'founding act' of culture?

Theory like this, along with novels like The White Hotel or The French Lieutenant's Woman, works to define the subject in terms rather different, in the end, from those of liberal humanist individualism and human essence. There is no transcending of the particularities of the historical and social system. The subject, in a novel like Midnight's Children, is constituted in a way that the theory would define as 'the individual in sociality as a language-using, social and historical entity' (Coward and Ellis 1977: 1). Such a definition almost has to, if not preclude, then at least challenge, the humanist faith in the individual as free, unified, coherent and consistent. The work of Benveniste, Lacan, and Kristeva has been important in changing how we can think about the subject. And such a change affects how we consider both literature and history, as the representations and recordings of subjectivity in language. Both become unstable processes in meaning-making, no longer final products of past and fixed meaning. In historiographic metafictions, all the various critically sanctioned modes of talking about subjectivity (character, narrator, writer, textual voice) fail to offer any stable anchor. They are used, inscribed, established, yes, but they are then abused, subverted, undermined. These novels are perhaps upsetting to many readers for exactly this reason.

None of these contradictions, however, invalidates the actual critique of liberal humanism. They do condition the degree of radicality of those contestations, perhaps, as does the fact that such critique can, in fact, be recuperated in the name of liberal humanist openness to all that is human. Notice this interpretation of the metafictional contesting of unified, coherent subjectivity by Charles Newman: 'To agree that art alone cannot give a complete image of man's self is potentially to reaffirm both the richness of our humanity and the possibilities of artistic enterprise' (Newman 1985: 96). Implied in this view of the artistic enterprise is a humanist valuing of complexity and universality, and also of authenticity and originality. And, as Rosalind Krauss has noted, in art, these values have served much wider ideological interests and are thus fuelled by more diverse institutions than just the restricted circles of 'professional art-making' (Krauss 1985: 162). The museum, the historian, the maker of art (and we might add, the publisher, the library, the university) - all have shared in this humanist 'discourse of authenticity' that has certified the original and repressed the notion of repetition and copy (that gives it its force). The postmodern questioning of authority has been amusingly described by William Gass as a decline in 'theological power, as if Zeus were stripped of his thunderbolts and swans, perhaps residing on Olympus still, but now living in a camper and cooking with propane. He $i s$, but, he is no longer a god' (Gass 1985: 265).

To stress the unavoidably textual and intertextual nature of both literature and history is not to obliterate the producer; it does change his/her status, though. In historiographic metafiction, the novelist and the historian are shown to write in tandem with others - and with each other. In $G$. , the narrator overlaps his own narration with a text of Collingwood's: 'the condition of [events] being historically known is that they should vibrate in the historian's mind' (Berger 1972: 55). The novel is not just plagiarizing Collingwood's text (in fact, some of the sources or intertexts, including this one, are provided in an introductory acknowledgement, as is the case in Banville's Doctor Copernicus as well). The novel shares the historian's view of historiography as both a contemporary event and related to self-knowledge. Just as the novel mixes historical and fictive events and personages, so its textual fabric mixes the historiographic and the novelistic.

Sometimes, however, postmodern fiction even more obviously uses the specific values of humanism in order to let them subvert themselves: the stubborn assertion and equally insistent undermining of both individuality and universality in Saleem Sinai's narrative in Midnight's Children, is perhaps the most blatant example. I am not at all sure that the result of this process is the 'revitalizing' of these particular parts of the humanist tradition because they 'deserve' to last (Wilde 1985: 347); I think the end result of the demystifying paradoxes is to ask us to question, but not to resolve. Like all parody, such subversion also inscribes what it undercuts, however, and so it may ironically work towards the enshrining of those values it exists to contest. But just as the postmodern is not automatically radical, despite its often leftist rhetoric of oppositionality, it does not automatically revitalize the tradition. It sits on the fence; it literally becomes a point of interrogation. Its ironies implicate and yet critique. It falls into (or chooses) neither compromise nor dialectic. As I see it, postmodernism remains questioning, and, for many, is unsatisfactory for that reason. This judgment is itself, perhaps, a comment on the strength of our liberal humanist heritage. 
5

Postmodernism is about art's dispersal, its plurality, by which I certainly do not mean pluralism. Pluralism is, as we know, that fantasy that art is free, free of other discourses, institutions, free, above all, of history. And this fantasy of freedom can be maintained because every work of art is held to be absolutely unique and original. Against this pluralism of originals, I want to speak of the plurality of copies. (Douglas Crimp)

Copies, intertexts, parodies - these are among the concepts which have challenged humanist notions of originality and universality. Together with positivistic science, humanism has also tended to mask what current theory wants to unmask: the idea that language has the power to constitute (and not only to describe) that which it represents According to this perspective, there can be no value-neutral discourses - not even science or history, and certainly not literary criticism and theory. These are the kind of issues that postmodern theory and practice bring to our attention. The art's interrogation of the values underlying our cultural practices, however, is always overt, always on the surface, not hidden in the depths to be unearthed by the discerning (deconstructing) critic. Indeed, the art often acts as a contesting of the criticism or theory. The disciplines of history and literary studies have been challenged by historiographic metafiction's problematizing of both historical knowledge and literary representation, by its foregrounding of the process of the production of facts out of events through definite ideological and literary practices (see Adler 1980: 250).

But, if postmodernism no longer privileges continuities nor values humanist essences, this does not mean that it is not more than willing to exploit the power of both. It is part of the paradox of both the fiction and the theory $I$ have been calling postmodern that they are willing to acknowledge, even as they contest, the relation of their writing to legitimacy and authority. For Hayden White, even to narrativize the events of the past is already to moralize, to impose closure on a story which did not end and whose constructed end suggests that there is a moral meaning inherent in those events (rather than in the narrative structuring of the historian) (White 1980: 18, 24, 27). Though challenged by Louis Mink (1981: 778) on the grounds that every story permits, but does not demand, a moral interpretation, White's point holds for the ideological, if not the specifically moral, as he himself argued earlier: 'there is no value-neutral mode of emplotment, explanation, or even description in any field of events, whether imaginary or real' (White 1976: 34). The shift from the humanist concern for the moral to a postmodern concern for the ideological is visible in White's work - as it is in much recent theory in other fields as well. Even the use of language itself is seen by White to entail less a moral than a particular political positioning of the user in relation to the world: 'all language is politically contaminated' (35). What Catherine Belsey challenges in the humanist reading of literature, could apply to the reading of history: 'What we do when we read, however "natural" it seems, presupposes a whole theoretical discourse, even if unspoken, about language and about meaning, about the relationships between meaning and the world, meaning and people, and finally about people themselves and their place in the world' (Belsey 1980: 4). But the perspective here is ideological, rather than moral. Despite obvious similarities, the contexts differ considerably. One difference is that race, gender, ethnicity, sexual preferences have all become part of the domain of the ideological and political, as the various manifestations of centralizing and centralized authority are challenged. While some French poststructuralist theory has argued that the margin is the ultimate place of subversion and transgression (e.g. Kristeva 1980: 92), another branch has shown how the margin is both created by and part of the centre (Foucault 1973: 10), that the 'different' can be made into the 'other'. Postmodernism tends to combat this by asserting the plurality of the 'different' and rejecting the binary opposition of the 'other'

Postmodern metafictions have looked to both the historiographic and fictional accounts of the past in order to study the ideological inscriptions of 'difference' as 'inequality'. In Fowles's A Maggot, the twentieth-century narrator fills in the background of the eighteenth century's sexism and classism, as it is needed, in order to explain his characters' actions - such as the 'crudely chauvinistic contempt' (Fowles 1985: 227) of the middle-class English lawyer, Ayscough, for his poor Welsh witness, Jones. We are told that the roots of such contempt lie in the real religion of the century, the 'worship, if not idolatry' of property (227): 'this united all society but the lowest, and dictated much of its behaviour, its opinions, its thinking' (228), including its notion of justice. Like many other postmodern fictions, this one is not content to say something about the past and stop at that. This novel forges a link with the present: 'Jones is a liar, a man who lives from hand to mouth . . . [yet] he is the future and Ayscough the past; and both are like most of us, still today, equal victims in the debtors prison of History, and equally unable to leave it' (231).

There are also links between the centre and the margin. The position of black Americans has worked to make them especially aware of the possible political and social consequences of art, but these writers know that they are still part of American society. Maxine Hong Kingston's articulation of this same paradoxical positioning is in terms of ChineseAmericans. When these ex-centrics visit China, she claims, 'their whole lives suddenly made.sense . . . They realize their Americanness, they say, and "You find out what a China Man you are"' (Kingston 1980: 295 ). This is the contradictory position too of Wiebe's Métis, Rushdie's Indian, Kogawa's Japanese-Canadian and of the many women, gays, hispanics, native peoples, and members of the working class, whose inscription into history in the sixties and since has forced a recognition 
of the untenable nature of any humanist concept of 'human essence', or of universal values that are not culturally and historically dependent. The social result of this is not necessarily 'the all-embracing and enervating cultural pluralism that dominates contemporary society' (Russell 1985: 241). Another result is the postmodern attempt to negotiate the space between centres and margins in ways that acknowledge 'difference' and its challenge to our supposedly monolithic culture, as defined by liberal humanism.

Feminist theory has clearly been one of the most potent decentring forces in contemporary thought, and its rhetoric has been largely oppositional (gender's binary oppositions are perhaps not that easily surmounted). Witness the opening of Judith Fetterley's The Resisting Reader: 'Literature is political. It is painful to have to insist on this fact, but the necessity of such insistence indicates the dimensions of the problem' (Fetterley 1978: xi). Feminism has, in fact, almost replaced the more traditionally political concerns (such as nationalism) in places like Quebec, where women artists and theorists are rearticulating power relations in terms of gender and language (but less as French versus English this time).

Historiographic metafiction has participated in this politicizing of sexuality in typically postmodern ways, insisting on both the history of the ideological issues and their continuing relation to art and society. The heroine of Susan Daitch's L.C. (1986) receives her political education through the aesthetic and the personal. The novel is set in Paris in 1848 , so the public dimension is overt. But it is the personal relations which the fictive Lucienne Crozier has with various artists, including the historical Delacroix, that teach her both about the role of art in politics and about the marginalized role of women in both domains: they are muses, models, observers, diversions. The novel's complex framing relates Berkeley 1968 to Paris 1848 (they are equally markers of revolutionary contexts). But the conclusions of both story and frame - outside those marked contexts - question the patriarchal values underlying (male) revolutions, but offer no positive substitute: Lucienne's journal manuscript is used and abused by those whose political and economic interests it can serve.

In Christa Wolf's No Place on Earth, two historical personages, the poets Kleist and Günderrode, are made to meet in fictional space. Their initial perception of the gender roles they must fulfil differ. Kleist looks at the woman poet and sees only her security:

She is provided for, whatever that may mean; she is not compelled to concentrate her thoughts on the most trivial demands of everyday life. It seems to him a kind of advantage that she has no choice in the matter. As a woman she is not placed under the law of having to achieve everything or to regard everything as nothing. (Wolf 1982: 107)

Günderrode's version of her fate as a woman is different: 'By the age of seventeen we must have accepted our fate, which is a man, and must learn to accept the penalty should we behave so improbably as to resist. How often I have wanted to be a man, longed for the real wounds, to which you men expose yourselves' (112). In fact, as the two poets realize, 'man and woman have a hostile relationship' within each of them: 'Woman. Man. Untenable words. We two, each imprisoned in his sex' (108). The postmodern answer to gendered oppositions is not androgyny, or at least not here; it is rather an interrogation of the very opposition upon which inequality is founded.

In historiographic metafiction, such interrogation is often directly connected to that of other similarly unequal oppositions, such as race and class. In Coetzee's novel, Foe, the enabling conceit of the text is that Defoe's Robinson Crusoe was indeed a real tale told to its author, but the teller was a woman, Susan Barton, and the tale somewhat different from the one we have come to know. In this novel, however, her awareness of the inequalities of gender do not save Susan from other ideological blind spots: she berates Cruso [sic] for not teaching Friday how to speak: 'you might have brought home to him some of the blessings of civilization and made him a better man' (Coetzee 1986: 22). The narrative's exploration of these 'blessings' and of Friday's status in their regard makes it another of the challenges to the liberal humanist -and imperialist - heritage that lives on in Coetzee's own nation, South Africa. Like Susan, Friday cannot tell his own story, but it is not because he has been silenced by a controlling male writer: here it is the white slave traders who literally (and symbolically) have removed his tongue. Susan shares the assumptions of her age, but her gender helps her see a little at least of her own ideological motivations: 'I tell myself I talk to Friday to educate him out of darkness and silence. But is that the truth? There are times when benevolence deserts me and I use words only as the shortest way to subject him to my will' (60). Language paradoxically both expresses and oppresses, educates and manipulates. Though Foe denies her charge, she asserts that his ignoring of her 'true' castaway story of Cruso is comparable to the slavers robbing Friday of his tongue (150). What she learns is to question the humanist assumptions underlying her own ironic claim that she is 'a free woman who asserts her freedom by telling her story according to her own desire' (131): her sex, like Friday's race and Foe's class, condition her freedom.

In theory, the work of feminists, Marxists and black critics, among others, has argued this kind of interaction of the discourses of the marginalized. They have done so in such a powerful way that many feel today that they have created a new cultural hegemony, in the Gramscian sense of a new set of values and attitudes which validates what is now a dominant class in its power. But within each group there is little sense of unity or power: some claim that feminism is the discourse of the white, middle-class woman. Alice Walker calls her fiction 'womanist' to set it apart from this discourse (see Bradley 1984: 
35). But there is a black feminist discourse, a Marxist feminist discourse, and, of course, a humanist feminist discourse. From a metatheoretical point of view, it is this plurality of feminisms that makes the postmodern valuing of 'difference' possible.

No acceptable non-totalizing alternatives may be available, but the questioning of the existing order should not stop for that reason. The interrogations of the 'different' form their own discourse, one that attempts to avoid the unconscious traps of humanist thought, while still working within its power-field. Like feminists, postcolonial theorists and artists are initiating their own discourse, with its own set of questions and strategies (see Bhaba 1983: 198). Black and gay critics now have quite a long discursive history. And all of these marginalized ex-centrics have contributed to the definition of the postmodern heterogeneous 'different' and to its inherently ideological nature. The new ideology of postmodernism may be that everything is ideological. But this does not lead to an intellectual or practical impasse. What it does is underline the need for self-awareness, on the one hand, and on the other, for an acknowledgement of that relationship-suppressed by humanism - of the aesthetic and the political. In E. L. Doctorow's words: "a book can affect consciousness - affect the way people think and therefore the way they act. Books create constituencies that have their own effect on history' (in Trenner 1983: 43). 